ORIGINAL ARTICLE

\title{
Land use dynamics under the Bolsa Floresta Program: a case study of the Uatumã Sustainable Development Reserve (Amazonas, Brazil)
}

\author{
Romero SILVA ${ }^{1 *} \oplus$, Anne-Elisabeth LAQUES ${ }^{2}$, Ana I.R. CABRAL ${ }^{3}$, Suzy-Cristina SILVA ${ }^{4}$, \\ Henrique PEREIRA ${ }^{4}$, Carlos SAITO ${ }^{1,5}$ \\ 1 Universidade de Brasília, Centro de Desenvolvimento Sustentável, Brasília, Brazil \\ ${ }^{2}$ Institut de Recherche pour le Développement, Montpellier, France \\ 3 Universidade de Lisboa, Instituto Superior de Agronomia, Centro de Estudos Florestais, Lisboa, Portugal \\ ${ }^{4}$ Universidade Federal do Amazonas, Centro de Ciências Ambientais, Manaus, Brazil \\ 5 Universidade de Brasília, Instituto de Ciências Biológicas, Departamento de Ecologia, Brasília, Brazil \\ *Corresponding author: romerogomes1@hotmail.com; (1) https://orcid.org/0000-0002-4553-3498
}

\begin{abstract}
The effectiveness of a program of payment for environmental services (PES) in the Brazilian Amazon was analyzed through an accurate mapping of deforested areas. The Bolsa Floresta Program (BFP) in Amazonas state (Brazil) was chosen as an example of a PES program that aims to compensate farmers for their commitment to zero deforestation of primary forests while opening swiddens only in secondary vegetation areas. However, the official measurement of opened swiddens is not effective since only deforested areas larger than 6.25 ha are mapped, whereas most areas opened for cassava crops are approximately 1 ha in size. The effectiveness of the BFP was evaluated in the Uatumã Sustainable Development Reserve (SDR). We tested a methodology for mapping areas from 0.45 ha upwards that have been opened for cassava swiddens. The years 2006 (before the implementation of the BFP), 2011, 2015 and 2019 were analyzed. The results indicated that $88 \%$ of the areas opened for swiddens were between 0.45 and 6.25 ha in size. After the implantation of the BFP, the cumulative total deforested area decreased, and there was a reduction in deforested areas in primary forests. An intensification of swidden cultivation was also observed, which could cause a decline in productivity. The monitoring by land-use zoning showed that the majority of opened areas were located in intensive use zones, following the rules of the SDR management plan. The results show the efforts of local families to fulfill the BFP rules.
\end{abstract}

KEYWORDS: swidden; cassava; PES, deforestation; land use zoning; environmental services

\section{Dinâmica de uso da terra no âmbito do Programa Bolsa Floresta: estudo de caso na Reserva de Desenvolvimento Sustentável do Uatumã (Amazonas, Brasil)}

\section{RESUMO}

A efetividade de um programa de pagamento por serviços ambientais (PSA) na Amazônia brasileira foi analisada através de um mapeamento detalhado de áreas desmatadas. O Programa Bolsa Floresta (PBF), no estado do Amazonas (Brasil), foi escolhido como um exemplo de PSA que visa compensar agricultores por aderirem ao desmatamento zero da floresta primária ao abrir roças somente em áreas de capoeira. Porém, a medição oficial das roças não é efetiva, visto que apenas áreas desmatadas maiores que 6,25 ha estáo sendo mapeadas, enquanto a maioria das áreas abertas para cultivo de mandioca possuem áreas de aproximadamente 1 ha. A eficácia do PBF foi avaliada na Reserva de Desenvolvimento Sustentável (RDS) do Uatumã. Testamos uma metodologia de mapeamento de áreas a partir de 0,45 ha abertas para roças de mandioca. Foram analisados os anos de 2006 (antes da implantação do PBF), 2011, 2015 e 2019. Os resultados indicam que 88\% das áreas abertas para roças tinham entre 0,45 e 6,25 ha. Após a implantação do PBF, a área total desmatada acumulada diminuiu e houve redução das áreas desmatadas em floresta primária. Também observamos uma intensificação da roça, o que pode ocasionar queda na produtividade. $\mathrm{O}$ monitoramento do zoneamento do uso da terra mostrou que a maioria das áreas abertas estão localizadas na zona de uso intensivo, seguindo as regras do plano de manejo da RDS. Os resultados mostraram os esforços das famílias para cumprir as regras do BFP.

PALAVRAS-CHAVE: roça; mandioca; PSA, desmatamento; zoneamento de uso da terra; serviços ambientais

CITE AS: Silva, R.; Laques, A.-E.; Cabral, A.I.R.; Silva, S.-C.; Pereira, H.; Saito, C. 2021. Land use dynamics under the Bolsa Floresta Program: a case study of the Uatumã Sustainable Development Reserve (Amazonas, Brazil). Acta Amazonica 51: 370-381. 


\section{INTRODUCTION}

The Brazilian Amazon has great importance for nature conservation and for the provision of ecosystem services (Strand et al. 2018). Nevertheless, it is increasingly threatened by anthropic activities (Barlow et al. 2020), such as the expansion of cattle ranching and soy cultivation (Barona et al. 2010; Van Vliet et al. 2013; Villa et al. 2018). The largest portion of deforestation takes place in large, private land estates (Moutinho et al. 2016) and 15\% of deforestation, until 2020, was within protected areas (INPE 2020). These areas include sustainable use reserves, which corresponds to IUCN category VI of protected areas - Protected area with sustainable use of natural resources (Dudley, 2008), where traditional local communities pursue the maintenance of their traditional ways of living.

In these areas, family agriculture is practiced by a slash-and-burn system to establish swiddens, which entails deforestation (Dutrieux et al. 2016; Jakovac et al. 2017). Therefore, the monitoring of these open areas by traditional peoples can bring elements to support more effective public policies, that promote a decrease in deforestation without negatively impacting traditional planting and living habits (Couto-Pereira 2010).

In this sense, payment for environmental services (PES) programs emerged to obtain more effective environmental conservation results (Lundberg et al. 2018) by adding extra income to families in return for conserving natural resources. In 2007, the government of Amazonas state adopted a version of a PES program as an instrument in its "State Policy for Climate Change, Environmental Conservation and Sustainable Development" (Amazonas 2007a). This program, called Bolsa Floresta Program (BFP: Forest Grant Program) was the first Brazilian PES program directed to people living in the protected areas. The BFP is implemented in 16 protected areas, covering almost 11 million ha and benefits 9,427 families, totaling 39,464 people (FAS 2019). The BFP aims to ensure gains, production activities and social benefits (FAS 2018). Adhesion to the program is voluntary and beneficiaries compromise not to open new swiddens in primary forest areas and to enroll and keep their children in school, among other components (Amazonas 2007b). The BFP proposes a voluntary approach with a focus on poverty reduction combined with nature conservation, but the social gain is low (Couto-Pereira 2010). Regarding conservation, the program had a positive effect on forest conservation, reducing deforestation by about $11 \%$ overall and up to $34 \%$ close to communities (Cisneros et al. 2020).

Monitoring of compliance with the rules of the BFP is carried out by Fundação Amazonas Sustentável (FAS), a non-for-profit organization delegated by the state government. FAS uses a system of 'yellow-card' warnings and does not penalize non-compliance immediately (Cisneros et al. (2029). Despite the tolerance with rule-breaking, $5 \%$ of BFP beneficiaries had the benefit suspended and $15 \%$ had the benefit canceled at the end of 2019, which lead to the emigration of families (FAS 2019).

Since 2010, FAS has implemented the deforestation monitoring in BFP areas using official data of the Satellite Deforestation Monitoring Project in the Amazon - PRODES (INPE 2019). This methodology does not allow the detection of deforested areas smaller than 6.25 ha (Câmara et al. 2006). The impact of monitoring only areas larger than 6.25 ha is evidenced by the detection of a $34 \%$ increase in the number of small clearings ( $<1 \mathrm{ha})$ in the Brazilian Amazon between 2001-2007 and 2008-2014, probably resulting from attempts to circumvent official deforestation monitoring (Kalamandeen et al. 2018). These findings highlight that, despite the high global accuracy and high quality of the mappings generated by PRODES (Maurano et al. 2019), there is need for more detailed, small-scale mapping of tropical forest openings. PRODES uses a mapping scale of 1:250000, which is an insufficient resolution for the detection of areas opened by traditional farmers that cultivate cassava (Manihot esculenta Crantz). In Amazonas state, for example, annually cultivated plots have sizes of 0.5 to 1 ha (Dutrieux et al. 2016). Therefore, it is urgent to obtain a more detailed mapping of opened areas for an efficient evaluation of PES that are based on minimizing deforestation.

In this context, we aimed (a) to develop a scanning analysis methodology that is capable of detecting swiddens, including those smaller than $6.25 \mathrm{ha}$, and (b) to evaluate whether the implementation of the BFP had an impact on the traditional agriculture system and on the protection of primary forests. To meet these objectives, a case study we selected the Uatumã Sustainable Development Reserve, in Amazonas state, as a case study, as this was the first protected area where the BFP was implemented.

\section{MATERIAL AND METHODS}

\section{Study area}

The SDR is a modality of the Brazilian system of protected areas located in Amazonas state that gives protection to populations whose existence is based on a sustainable system of natural resource exploitation. (Article 21 in Amazonas 2007b). The Uatumã SDR was created in 2004 with an area of 4,244.30 $\mathrm{km}^{2}$ and is located $200 \mathrm{~km}$ in a straight line from the Amazonas state capital of Manaus, in the municipalities of São Sebastião do Uatumã and Itapiranga in northeastern Amazonas state (Figure 1). Its management plan ${ }^{1}$ was implemented in 2009 (IDESAM 2009) and updated in 2017 (SEMA 2017). One of the main points of the plan is land-use zoning, determined through participative mapping in 2007, which delimits specific

1 According to Brazilian law for protected areas (BRASIL 2000), the management plan is a mandatory document, in which the objectives of the reserve are described, its land-use zoning is established and the rules that must govern the use and management of resources of the protected area. 

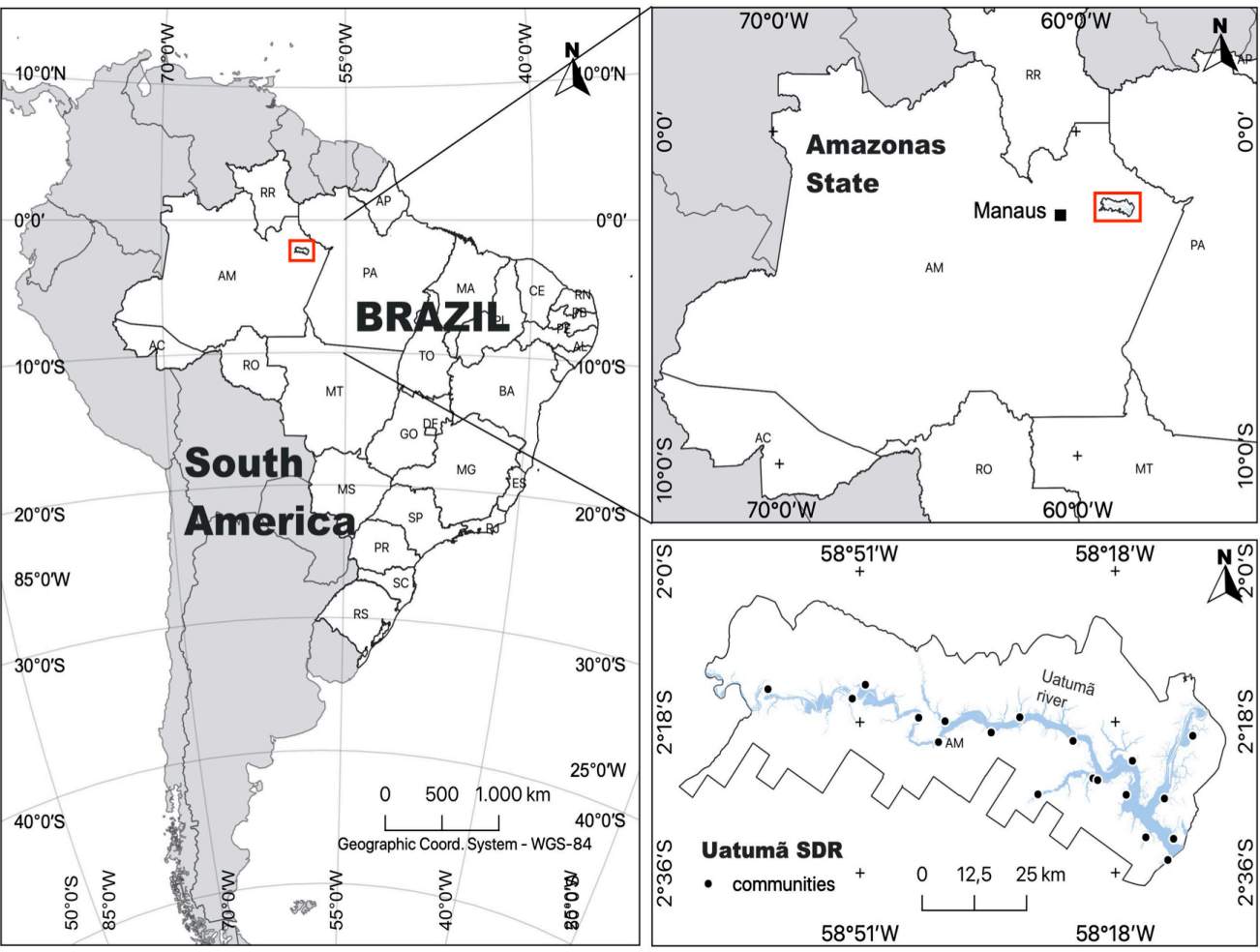

Figure 1. Location of the Uatumã Sustainable Development Reserve in northeastern Amazonas state, Brazil. This figure is in color in the electronic version.

areas to be used for the practice of agriculture, extractive activities and forest preservation: 1) intensive use zones (where swidden openings are allowed); 2) extensive use zones, defined as conservation areas (where extractive activities are allowed); and 3) protection zones, delimited for the preservation of biodiversity and local environments, restricted for limited use and full protection (IDESAM 2009).

The Uatumã SDR contains 20 communities distributed along the banks of its main river (Uatumã). According to the latest demographic and socioeconomic assessment, the reserve has 361 families and a total of 1,644 residents, with monthly family incomes between US\$70.06 and US\$ 400.87 (considering the average exchange rate of one USD to the Brazilian Real in 2019 as 3.95). The income sources of these families include agriculture, retirement pensions, wage labor, tourism, fishing, extractivism and livestock (SEMA 2017). Of these activities, agricultural practices based on the slash-andburn system associated with the cultivation of cassava for the production of flour stand out.

Cassava flour is one of the main sources of income in the study region, and the inhabitants consume cassava daily as a staple food. Cassava swiddens are cultivated in small areas (maximum of $3 \mathrm{ha}$ ) and on terra firme (never flooded). The planting rotation cycle of cassava consists of slashing and burning the forest (primary or secondary forests), cultivating the soil for a three-year period and leaving it to lie fallow for a period that can be either short (two to seven years) or long (more than 15 years) (Jakovac et al. 2015). The number and frequency of planting cycles depend on the necessity of the farmer, and planting cycles are of particular ecological importance in this system, because they greatly affect the capacity of the forest to regenerate after the abandonment of the land (Dutrieux et al. 2016). Other food crops that stand out in the swidden areas of the Uatumá SDR are bananas (Musa spp.), sugar cane (Saccharum officinarum L.), maize (Zea mays L.), watermelon (Citrillus lanatus L.) and pepper (Capsicum chinense Jacq.) (SEMA 2017).

Another source of income for the resident families of the Uatumã SDR is the BFP itself, which includes $83 \%$ of the resident families of the reserve. The average annual investment of the BFP per family is of US\$151.98 (FAS 2018), in the form of fixed monthly payments of US\$ 12.65 per family (Viana et al. 2012; Laques et al. 2018).

\section{General methodological approach}

To assess compliance to the rules established in the BFP related to the opening of swidden areas and the deforestation of primary forests, mapping of the areas that have been opened for swiddens was carried out using satellite images. Since the average size of swiddens ranges from 0.5 to 1 ha (Dutrieux et al. 2016), we chose to map areas larger than 0.45 ha. This value refers to an area larger than five pixels in a mapped 
Landsat image and is the value closest to the limit of 0.5 ha. First, the sizes and quantities of areas opened for swiddens were identified, considering the values in the year prior to the implementation of the BFP (2006) and three different years following its implementation. The mapped swiddens were overlayed year-on-year to determine the intensification degree of swidden opening. Finally, we overlayed the mapped opened areas with the land-use zoning and primary forest layers.

\section{Analyzed years}

The temporal selection of images was conducted based on important public-policy milestones: a) the creation of the SDR in 2004 and the creation of the BFP in 2007, which established the prohibition of deforestation for swidden opening in primary forests; $b$ ) the beginning of BFP payments to families in 2008; c) the implementation of the management plan of the SDR in 2009, after its approval in December 2008, including the rules regarding land-use zoning; and d) the revision of the management plan in 2017.

Based on this chronology, we chose 2006 as the initial year for analysis as the most recent year without any imposition of BFP rules or the management plan in the reserve. The second analyzed year was 2011, when both the BFP started and the management plan was in force, and two other years at four-year intervals (2015 and 2019). This timestep was chosen knowing that the cycles of opening new areas for cassava cultivation last an average of three years (Dutrieux et al. 2016; Jakovac et al. 2015, 2016).

\section{Mapping of swiddens}

The areas opened for swiddens were mapped by applying the normalized difference moisture index, the NDMI (Vogelmann and Rock 1988), to satellite images provided by the Landsat Thematic Mapper (TM) and Operational Land Imager (OLI) sensors with a spatial resolution of $30 \mathrm{~m}$. These images were accessed on the websites of INPE and USGS. This database and all used in this case study are represented at the top of the methodological flowchart (Figure 2).

After obtaining the NDMI values for each year, the optimal threshold values to identify swidden areas were selected to produce binary maps of swidden areas and other areas. The threshold choice was made by visual analysis after successive tests of the NDMI ranges for all years. The same thresholds were used for all years that were mapped. Empirically, we found that it was possible to identify agricultural areas using a threshold value between 0 and 0.3 , except in 2015, when the threshold value ranged between 0 and 0.12 . A strong El Niño in 2015 and 2016 (Jiménez-Muñoz et al. 2016), led to a strong decrease in rainfall and an intense drought that altered the landscape, consequently impacting the spectral differences in the satellite images.

We also considered the testimony of local residents during field research conducted in 2017 and 2018, who informed that swiddens are not opened in flood or ebb areas of the river, in accordance with the practices described in Jakovac et al. (2015). Therefore, to exclude eventually opened areas mapped in floodplain zones, it was necessary to map watercourses and their variations along riverbanks. A baseline map of watercourses that considered all studied years was obtained by extracting the water classes from the maps (2006, 2011, 2015) obtained through the MapBiomas website. The year 2019 was missing since this information was unavailable at the time of the analysis.

Clouds and shadows were manually delineated in vector format and later converted to raster format, obtaining a clean area of analysis that corresponded to $1.73 \%$ of the total reserve area. These areas were excluded from the subsequent analysis. After the exclusion of flood zones and clouds/shadows, the size (in hectares and number of polygons) of areas occupied by swiddens were calculated for each studied year, in order to analyze the evolution of swidden size and number after the implantation of the BFP. All geospatial operations (area calculation, overlaps and number of polygons) were performed in QGIS software.

We also overlaid the mapped data on a year-by-year basis to assess whether there was an increase in agricultural intensification. The assumption is that the degree of intensification increased whenever the swiddens were repeatedly opened in the same places throughout the studied years, indicating that there was low rotation in the opening of swidden areas. Thus, intensification was proportional to the interannual increase in the number of overlapping swidden polygons. The year-by-year overlap was calculated in absolute values and percentage of overlapping polygons (with intersection area $\geq 0.45 \mathrm{ha}$ ).

\section{Data from the management plan}

To assess the opening of swiddens in the context of the landuse zoning established by the SDR management plan, the maps of the areas opened for swiddens in the studied years were overlaid with the limits of each zoning class. We used information on land-use zoning available from the Amazonas State Environment Secretariat - SEMA (IDESAM 2009). Since mapped polygons could be located on the boundaries of zones, the methodological standard adopted here was to consider a swidden as pertaining to a certain zone whenever $50 \%$ or more of its area was inserted in that zone.

The maximum size of swiddens per family was limited to 3 ha, with exceptions when authorized by SEMA. There was no data available on the swidden area opened per family or on the exact number of families that opened swiddens each year. Therefore, we estimated the average size of swidden area per family in each land-use zone (protection, extensive and intensive-use zones) by dividing the total mapped swidden area in each land-use zone by the number of families in the SDR in 2006 (257 families, IDESAM 2009) and 2015 (393 


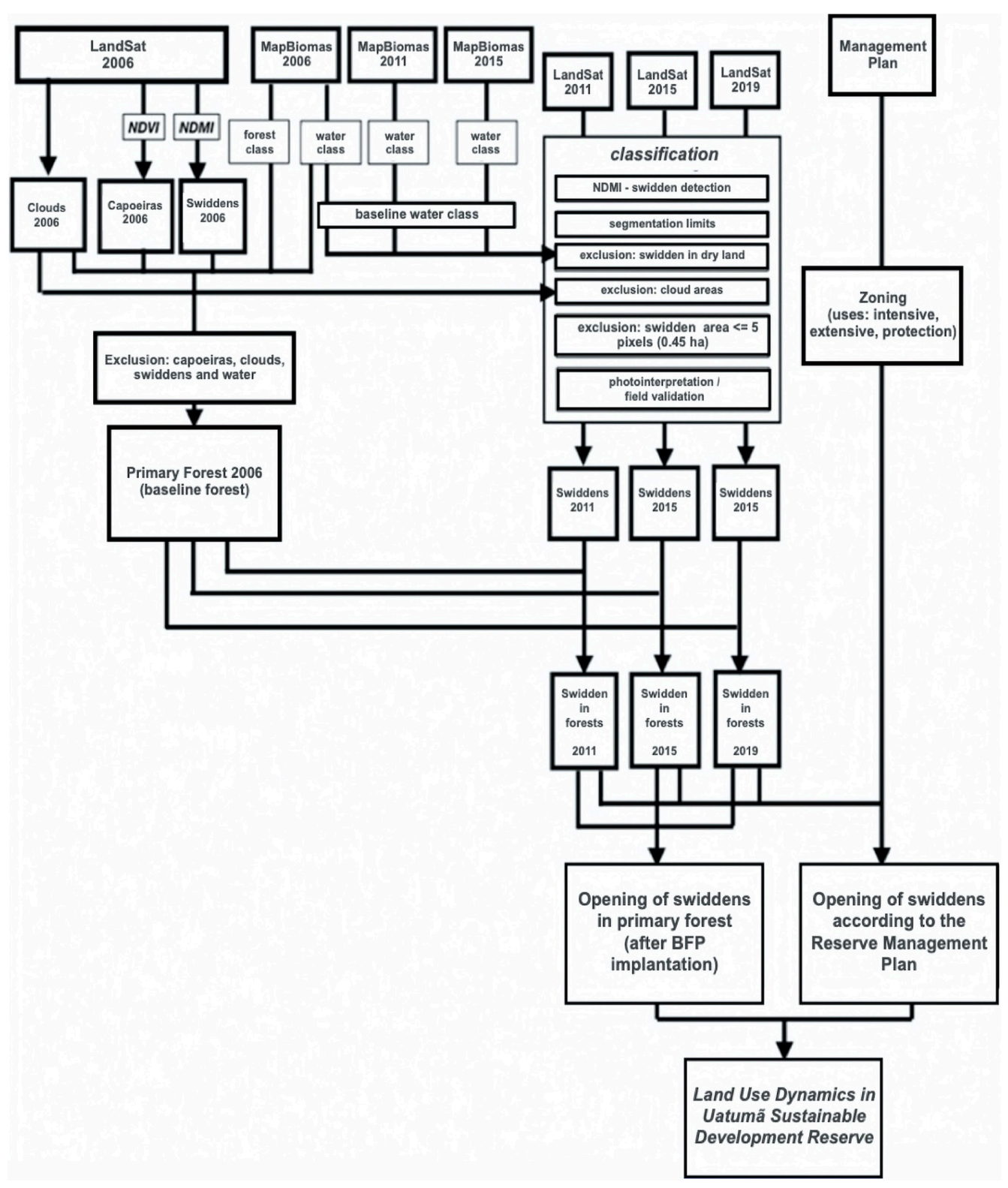

Figure 2. Flowchart of methodological steps for the mapping of areas opened for swiddens in the Uatumã Sustainable Development Reserve (Amazonas, Brazil) for analysis of compliance with the reserve's management plan regarding soil use zoning and with Programa Bolsa Família regarding zero deforestation in primary forest. 
families, FAS 2019). No demographic data was available for 2011 and 2019.

\section{Mapping of primary forest}

The location of new swidden openings in primary forest areas was quantified to evaluate compliance with the BFP and/or SDR management plan. To maps the primary forest areas within the SDR, we used the forest classes mapped by MapBiomas in 2006. To update this map, we excluded areas that were classified as primary forest in 2006 but later mapped as swiddens (according to the previously described method) or secondary vegetation (locally known as capoeira).

To obtain the secondary forest areas, the normalized difference vegetation index (NDVI) was determined from Landsat TM and OLI satellite images (Myneni and Williams 1994) to determine the value thresholds that best represented this class. The thresholds adopted for secondary forest identification in 2006 were between 0.83 and 0.88 . These thresholds were used to obtain binary images representing maps of secondary forest areas.

\section{Field data}

Two field trips were made, in August 2017 and October 2018, to assist in the characterization of swidden areas opened for cassava cultivation. The data were obtained through interviews made during guided treks (Evans and Jones 2011) with residents of the SDR and beneficiaries of the BFP. The collected information included the characteristics of opened cassava swiddens (swidden area, when the swidden was opened and abandoned, and planting techniques), and their geographic coordinates obtained via GPS (Garmin, model Etrex 30x).

Eight communities that accessed the BFP were visited: (1) Nossa Senhora do Perpétuo Socorro Community (Maracaranã); (2) Manaim Community; (3) Santa Luzia do Caracarana Community; (4) Ebenezer Community; (5) São Francisco do Caribi Community; (6) Nossa Senhora do Livramento; (7) Santa Luzia do Jacarequara and (8) Nova Jerusalém do Amaro Community. Fifteen formal interviews were made with authorization of SEMA (official permissions \# 021/2016 and 131/2018 - DEMUC/SEMA/ AM) and license from the Research Ethics Committee (CEP) (certificate of presentation of ethical appreciation $n^{\circ}$ 95385318.7.0000.5540). We used a structured questionnaire with open and closed questions related to the use of swiddens and secondary forests regarding the rules of the BFP.

\section{RESULTS}

The majority (88\%) of the areas opened for swiddens were between 0.45 ha (minimum area mapped) and 6.25 ha in size. Relative to 2006 (prior to the implantation of the BFP), there was an increase of approximately 2,000 ha in the total area of swiddens in 2011, and a decrease in 2015 and 2019 (Figure 3). In contrast, the number of polygons identified in 2019 (520 polygons) was higher than in 2006 (495 polygons), indicating greater fragmentation of new swidden areas.

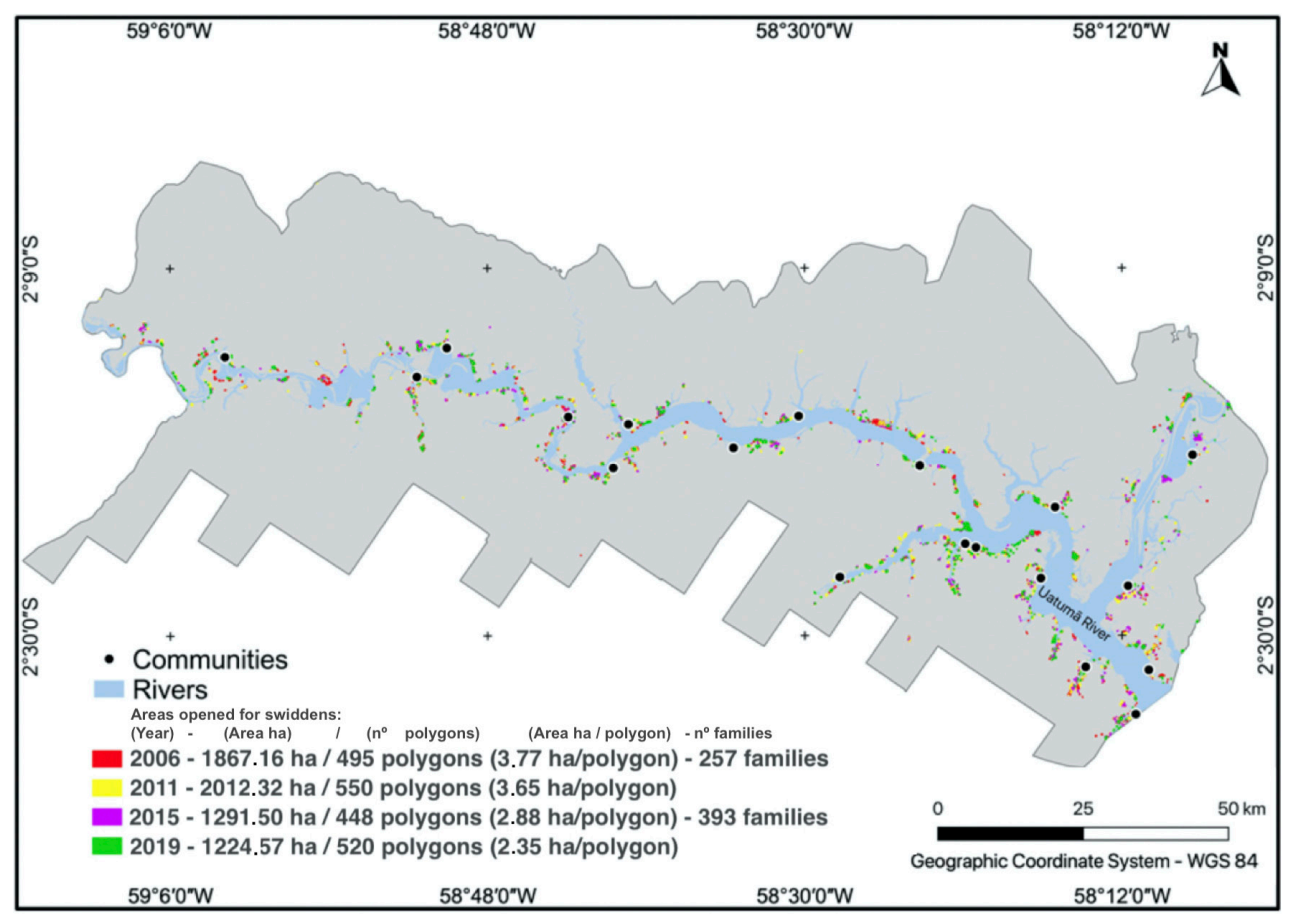

Figure 3. Swidden areas opened in 2006, 2011, 2015 and 2019 in the Uatumã Sustainable Development Reserve (Amazonas, Brazil). This figure is in color in the electronic version. 
There was an increase of 136 families to the population of the SDR from 2006 to 2015 (Figure 3), yet there was a decrease of 32 families in 2016 relative to 2015 (FAS 2019). In 2019, although there were no official demographic data available, the information gathered during field trips indicated that many families moved from the SDR, pointing to a decreasing population trend since 2015.

According to the management plan, the maximum size of swiddens should be 3 ha per family. In 2006 (prior to BFP), average swidden size per family was 7.7 ha, well above the maximum size of 3 ha per family later established by the management plan. In 2015, average swidden size per family was $3.2 \mathrm{ha}$, a value close to the allowed limit (Figure 3). After the implantation of the BFP, the year-by-year overlap of opened areas increased to approximately $60 \%$ (Table 1), indicating a low rotation of area opening, which leads to greater soil intensification.

In all years, the largest swidden area was located in the intensive use zone (Figure 4). In 2015, there was an expressive

Table 1. Overlapping values (absolute number and percentage) of areas opened for swiddens for all combinations between analyzed years (2006, 2011, 2015 and 2019) in Uatumã Sustainable Development Reserve (Amazonas, Brazil). Values in bold indicate overlap above $60 \%$.

\begin{tabular}{lccc}
\hline & 2006 & 2011 & 2015 \\
\hline 2011 & $283(57 \%)$ & - & - \\
2015 & $173(35 \%)$ & $223(61 \%)$ & - \\
2019 & $196(40 \%)$ & $266(69 \%)$ & $283(63 \%)$ \\
\hline
\end{tabular}

reduction of $40 \%$ in the swidden area located in the intensive use zone relative to 2011. This tendency persisted in 2019, with a $15 \%$ reduction in swidden area compared to 2015 . In the extensive use zones, a decrease of $30 \%$ in swidden area was observed in 2015 relative to 2011 , and an increase of $10 \%$ in 2019 relative to 2015 .

There were few swidden areas in protection zones in all years, increasing in only 6 ha throughout the period, from approximately 13 ha in 2011 , to 19 ha in the following years. The three areas inside protection zones containing swiddens are highlighted in Figure 5. In areas 1 and 2 (numbers on the map), the swiddens were mapped in the three years (2011, 2015, and 2019). In area 1, the opened swiddens follow the riverbank of a tributary of the Uatumá River, likely due to ease of access. The swiddens in area 3 were mapped only in 2019, and are located at the limit of the zone, as are the swiddens in area 2.

The average size of swidden polygons decreased throughout the analyzed years, even considering that one polygon can represent swiddens of more than one family (Table 2). There was no increase in polygon size over 3 ha in 2019.

The swidden area in primary forest decreased after 2006 (Figure 6), particularly in 2015 relative to 2011, with a decrease of $42 \%$, and in 2019 relative to 2015 , with a further decrease of $25 \%$. In 2011, swiddens in primary forest corresponded to $21.7 \%$ of the total swidden areas, while in 2015, this percentage fell to $19.6 \%$, and to $15.6 \%$ in 2019 . The number of opened areas in primary forest increased in 2015 (Figure 6), following the trend in other land-cover types.

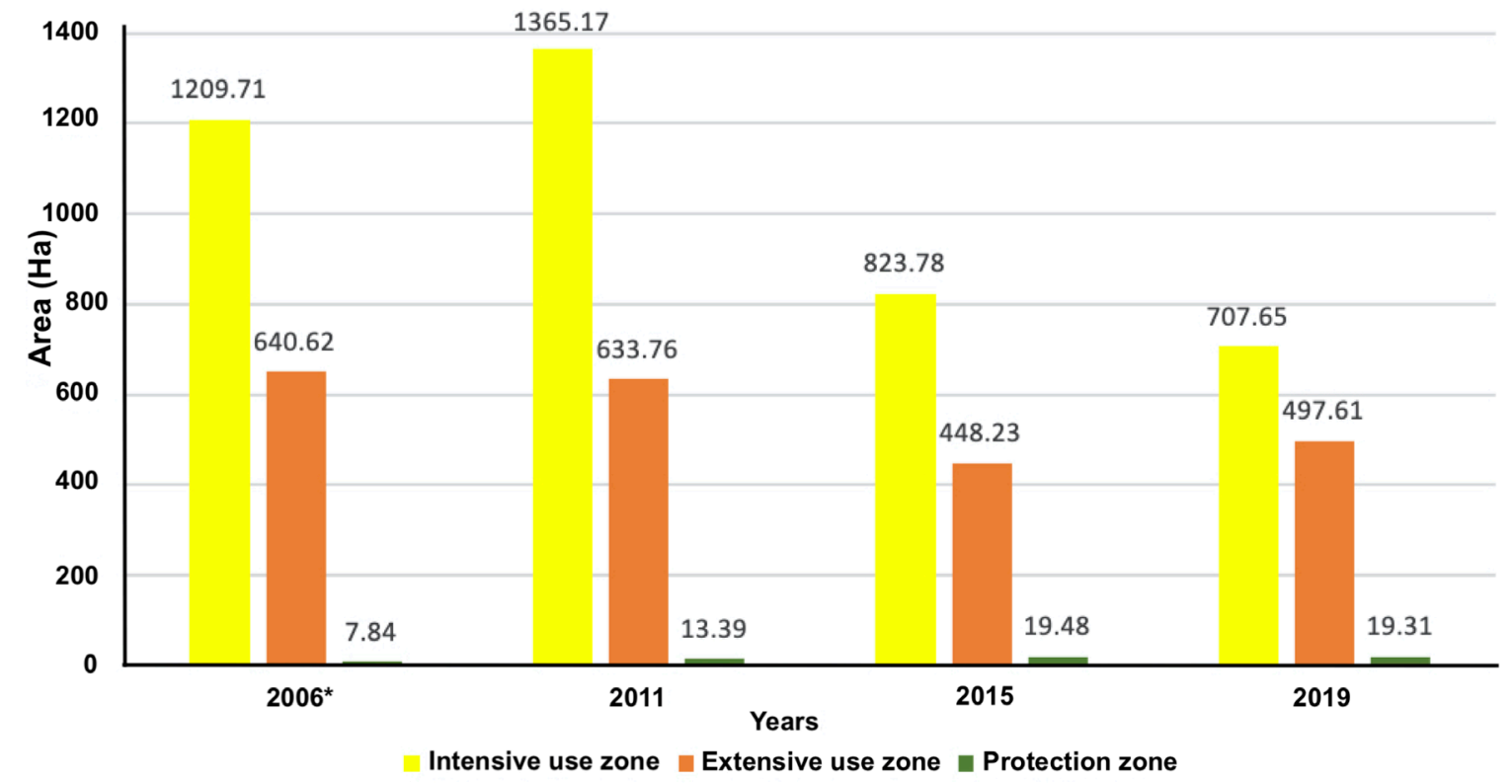

Figure 4. Total swidden area opened in each land-use zone established in the Uatumã Sustainable Development Reserve (Amazonas, Brazil) in 2006, 2011 , 2015 and 2019. The asterisk indicates the year prior to the implementation of the management plan. This figure is in color in the electronic version. 


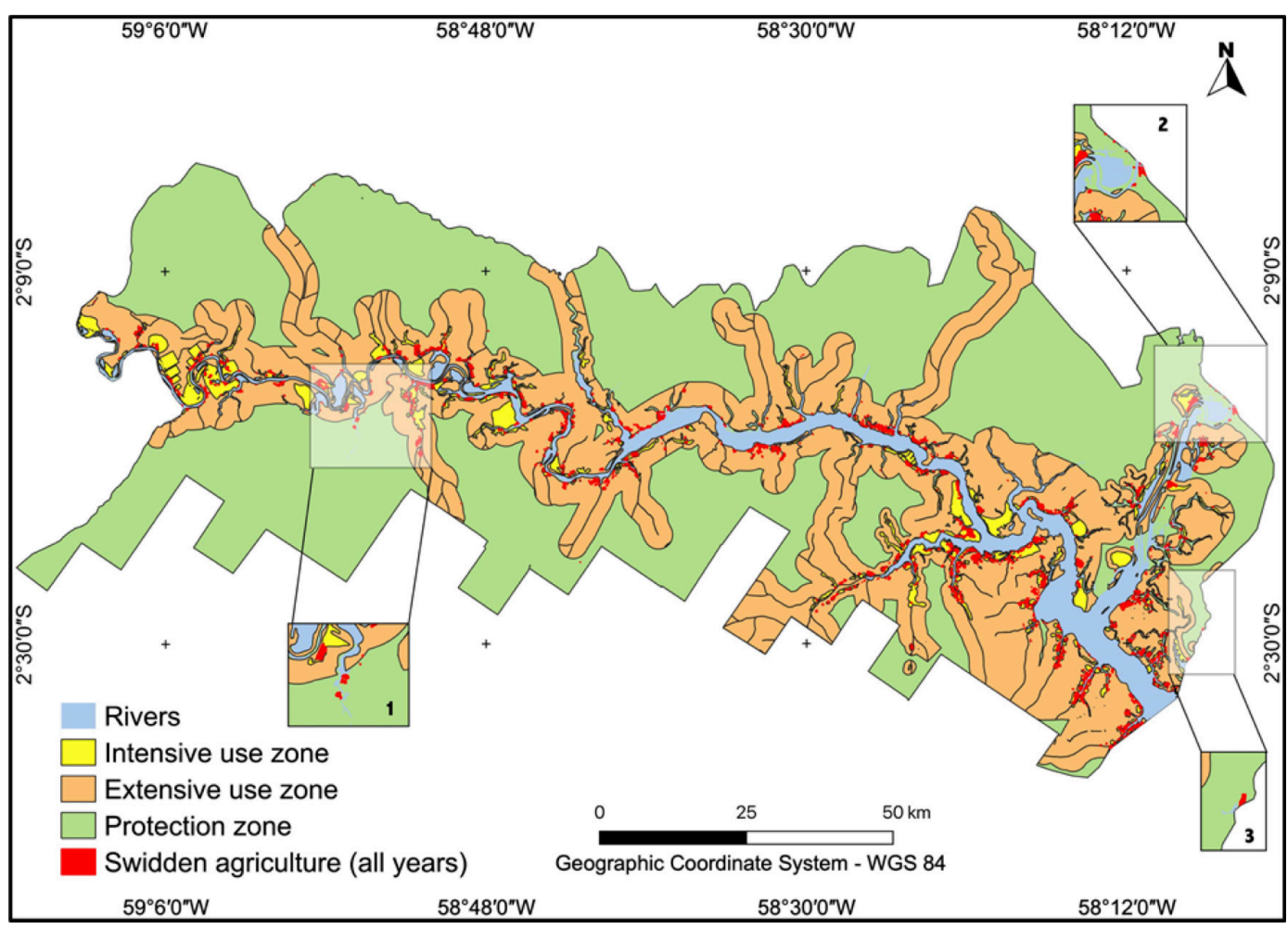

Figure 5. Swidden areas opened in protection zones (highlighted areas 1,2 and 3) within Uatumã Sustainable Development Reserve (Amazonas, Brazil) in the period from 2006 to 2019. This figure is in color in the electronic version.

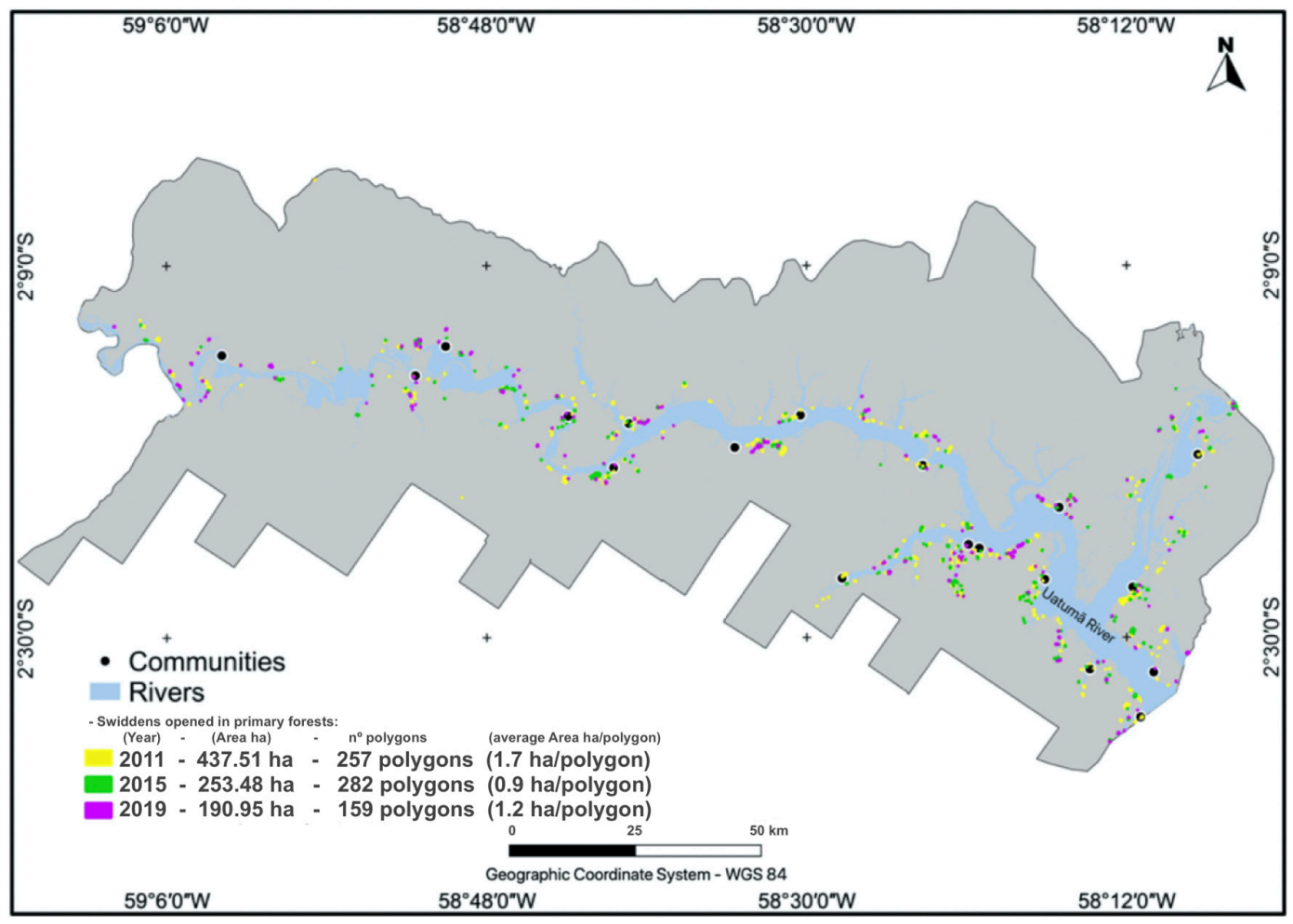

Figure 6. Distribution of swidden-area polygons in Uatumã Sustainable Development Reserve (Amazonas, Brazil) in 2011, 2015 and 2019. Total swidden area, number of polygons and average area per polygon for each year are indicated in the map legend. This figure is in color in the electronic version. 
The average size of swidden polygons in primary forests was much smaller than the maximum size of 3 ha allowed in the management plan (1.7 ha in 2011, 0.9 ha in 2015, and 1.2 ha in 2019).

In 2019, swidden areas in primary forest were mostly opened in the extensive use zone, unlike in previous years, when they were concentrated in the intensive use zone (Figure 7; Table 3). Considering only areas opened in primary forest in 2019, for example, we mapped 190.9 ha (Table 3), while the PRODES mapping, which is used for monitoring by FAS, mapped only 67 ha.

Table 2. Average area (ha) of swidden polygons mapped by land-use zone in the Uatumã Sustainable Development Reserve (Amazonas, Brazil) in 2011, 2015 and 2019 .

\begin{tabular}{lccc}
\hline Years & Intensive use & Extensive use & Protection area \\
\hline 2011 & 4.25 & 2.84 & 2.23 \\
2015 & 3.35 & 2.32 & 2.44 \\
2019 & 2.59 & 2.12 & 1.61 \\
\hline
\end{tabular}

\section{DISCUSSION}

Once the majority of the areas opened for swiddens were smaller than 6.25 ha, the minimum area mapped by PRODES, the current monitoring protocol of the BFP is not able to identify most swiddens in the SDR. This shows the need for a monitoring methodology for the BFP that allows a higher resolution for swidden identification, as the one proposed here, and that the current methodology should be reviewed.

During the field trips, we perceived that the number of polygons mapped did not reflect the number of swiddens per family, as swiddens tend to be opened contiguously and thus one mapped polygon can represent more than one familial swidden. Therefore, the contrast between the increase in the number of polygons and the decrease in the total size of areas opened for plantations deserves attention, as it suggests a process of family dissolution and group dispersal in the SDR. More specific studies are needed to assess the socioeconomic and environmental impacts related to the increased fragmentation process of forest areas implicated in this tendency of swidden clustering.

In addition to the decrease in the total swidden area and the increase in the number of families, which reduce the

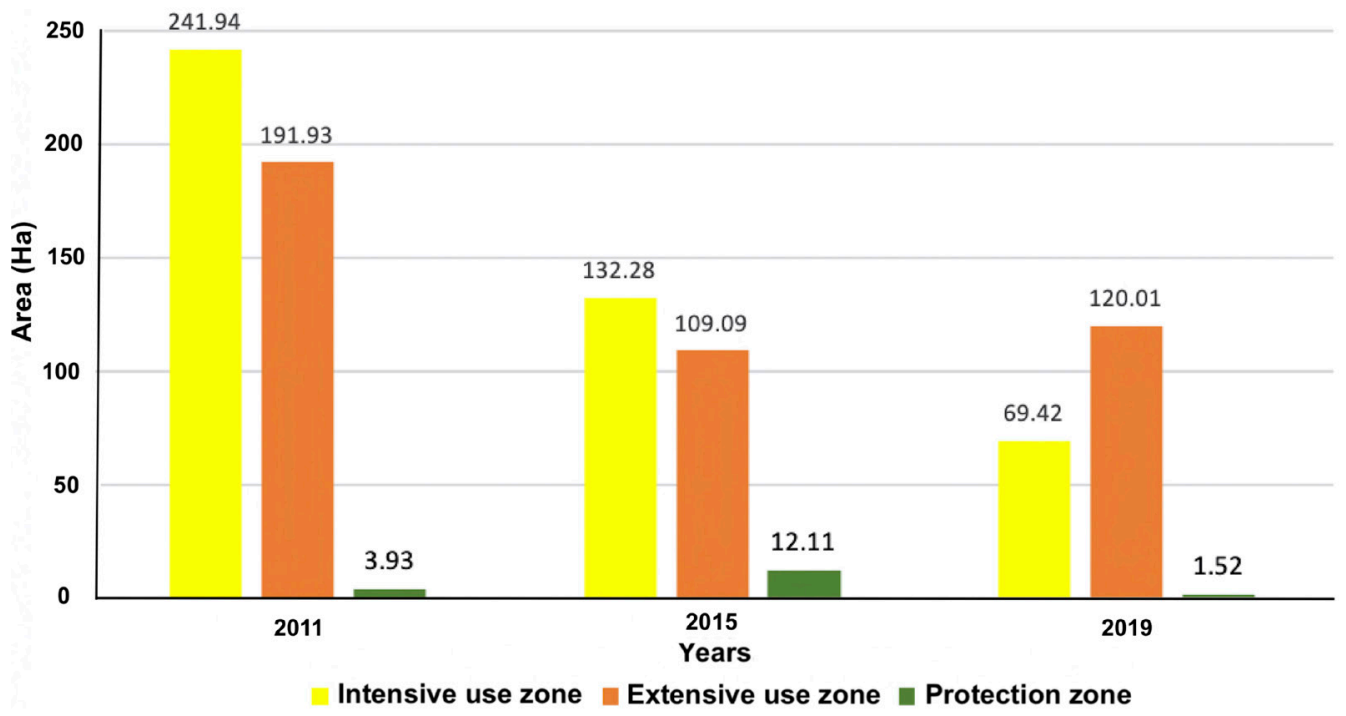

Figure 7. Total swidden area opened in primary forest in each land-use zone in the Uatumã Sustainable Development Reserve (Amazonas, Brazil) in 2011,2015 and 2019. This figure is in color in the electronic version.

Table 3. Total area of swiddens opened and area of swiddens opened in primary forest in Uatumã Sustainable Development Reserve (Amazonas, Brazil) in 2011,2015 and 2019. The proportion of swiddens in primary forests relative to the total area is also shown.

\begin{tabular}{|c|c|c|c|c|c|c|c|c|c|c|c|c|}
\hline & \multicolumn{3}{|c|}{ Intensive use } & \multicolumn{3}{|c|}{ Extensive use } & \multicolumn{3}{|c|}{ Protection area } & \multicolumn{3}{|c|}{ All zones } \\
\hline & 2011 & 2015 & 2019 & 2011 & 2015 & 2019 & 2011 & 2015 & 2019 & 2011 & 2015 & 2019 \\
\hline Total area (ha) & 1365.1 & 823.7 & 707.6 & 633.7 & 448.2 & 497.6 & 13.3 & 19.48 & 19.3 & 2012.3 & 1291.5 & 1224.5 \\
\hline Primary forest (ha) & 241.9 & 132.2 & 69.4 & 191.6 & 109.0 & 120.0 & 3.9 & 12.11 & 1.5 & 437.5 & 253.4 & 190.9 \\
\hline Primary forest (\%) & 17.7 & 16.0 & 9.8 & 30.2 & 24.3 & 24.1 & 29.3 & 62.1 & 7.8 & 77.3 & 102.5 & 41.8 \\
\hline
\end{tabular}


swidden to family ratio, it is important to note the presence of remaining pasture areas. Due to spectral similarities, we may have mapped pastures as swiddens, in which case the actual swidden to family ratio would be smaller. Our field observations indicated that pasture areas are larger, measuring about 40 hectares (measured in 2018). Before the creation of the SDR, raising livestock was the main economic activity of almost every community in the area, as a way to obtain financial security when the income from agriculture was insufficient (Gomes and Lacerda 2015). The raising of livestock was prohibited when the SDR was implemented.

Another reason for the decrease in swidden areas in intensive use zones, the population decrease observed in 2015 and 2019 may be the low price of cassava flour (the main byproduct of cassava). The average value of cassava flour from 2014 to 2020 was US\$ 0.25 per kg (CONAB 2020), a value that, according to the residents, brings low financial return. Also, according to residents, the fall in the price of cassava flour led to the migration of many residents from the reserve to other villages and those who stayed tend to decrease cassava production.

The fact that more than half of the areas that were opened post-implementation of the BFP were repeated in the same location, indicated that there has been a more intensive use of swiddens after the implantation of the BFP and an increase in the intensification of soil use. For the cultivation of cassava, a long fallow period ( $>15$ years) is important to restore the original soil conditions (Lintemani et al. 2020). The intensification of soil use for cassava cultivation makes the production system less sustainable (Villa et al. 2018) and the implementation of repetitive cycles in the same area has a strong effect on swidden productivity, decreasing soil fertility and increasing weed infestations (Van Vliet et al. 2012; Jakovac et al. 2016). Thus, the slight increase in swidden area in extensive use zones in 2019 (compared with 2015) may be a first indication of noncompliance with the BFP rules, which require the concentration of swiddens in intensive use zones. However, three factors must be considered in this context.

First, the overlapping of zoning layers with the mapping of swiddens in 2006 showed that a representative portion of swiddens (649.6 ha) already existed in the area that was later established as an extensive use area by the management plan.

Second, the areas assigned as intensive use zones, where swiddens can be opened, represents just $3.8 \%$ of the total area of the SDR, and also includes the location of housing nuclei, churches, soccer fields, small markets, and riverbanks that go through the SDR. This likely lead to a shortage of areas for cultivation, especially considering that the system of cassava cultivation requires an area that allows culture rotation and a period of fallow (Jakovac et al. 2016; Pérez et al. 2019).

Third, the limits of the land use zones may not be clear to the residents. The overlaying of the swidden mapping with the land use zoning map showed that many swiddens overlapped the limits of intensive and extensive use zones. While it is relatively easy to determine limits and overlaps in the GIS environment, there is no clear delimitation of the land use zones in the field, which can easily lead to new swiddens invertedly being opened in a prohibited zone. This fact goes back to the criticisms listed by Gebara and Agrawal (2017), concerning the lack of participation of local residents in the planning and implementation of the BFP.

Therefore, before judging compliance with BFP rules, it is important to determine to which extent the BFP beneficiaries are capable of recognizing the proposed zoning borders in the field. It is equally important to analyze if the land use zoning allowed for a scenario of population growth (as occurred from 2006 to 2015) and the necessity of new areas for the continuity of the cassava cultivation rotation system. Any conclusion regarding the impertinence of opening areas for swiddens in extensive use zones requires caution.

The opening of areas in primary forests in protection zones, though representing a very small amount of the total opened areas in the SDR, demand greater attention from reserve managers. Protection zones are destined strictly for environmental preservation, and the areas opened in these zones are located on the border areas of the SDR or close to rivers, suggesting ease of access. The borders of protected areas are the most vulnerable to deforestation (Paiva et al. 2020). It is possible that these areas were opened by nonresidents of the SDR and, consequently, configure an environmental crime. Thus, monitoring of forest suppression in protection zones needs to be more effective.

After the implantation of the BFP, the swidden opening in primary forests decreased, corroborating the analysis of Cisneros (2010) for the reserves that adopted BFP. However, areas where the BFP was implemented already had low trends in deforestation (Couto-Pereira 2010; Börner et al. 2013; Agustsson et al. 2014). Furthermore, unlike those who exploit forests in a predatory way for economic purposes, most of the BFP beneficiaries open up areas in the forest for subsistence (Couto-Pereira 2010).

The use of primary forests for cassava cultivation is necessary when demand for fertile soil increases with population growth (Van Vliet 2013). Independently of BFP rules, new swidden areas are still expected to be opened in primary forest, as the management plan allows it inside intensive use zones with authorization from reserve managers. Thus, the incorporation of new swidden areas in primary forests will happen for newly constituted families, new immigrants, or for families that do not have a sufficient number of swidden areas (IDESAM 2009).

Our results show that, in general, there was a tendency to comply with BFP rules after the implementation of the program, as there was a decrease in the total and average size of opened swidden areas, the majority of swiddens were located in the area of intensive use and the opening of areas in primary forest decreased. On the other hand, we also 
showed the negative impacts of BFP implementation in the intensification of land use and the tendency to increase swidden opening in the extensive use zone. In this sense, we agree with Couto-Pereira (2010) in demanding that BFP managers pay more attention to the effects of BFP rule enforcement on the vulnerability of the low-income residents who depend on forest resources. It is important to highlight that, in addition to being a source of income, cassava cultivation is part of the culture of the local communities and must be preserved. Thus, the BFP needs to be reevaluated to reach beyond environmental gains and ensure the achievement of the broader goal of sustainable development reserves, that includes the economic security and preservation of cultural integrity of local communities (Couto-Pereira 2010).

\section{CONCLUSIONS}

The methodology proposed in this study made it possible to evaluate the effectiveness and possible impacts of the BFP and to understand the temporal and spatial dynamics of swidden opening. Although most swiddens complied with the landuse zoning rules, there was a tendency to increase the opened areas in the off-limit extensive use zones. SDR managers need to be aware of these trends and discuss them with local communities, as they seem to indicate that the assigned intensive use zones are insufficient and/or that the residents are not clear about the limits between land use zones. Our results also showed that the BFP was successful in the promotion of zero deforestation in primary forests. On the other hand, we showed that most swiddens are being established over old swiddens, resulting in intensified soil use and reduced productivity, indicating the effort of BFP beneficiaries to avoid opening new swiddens in primary forest. The imposed rules are important, and our study shows that families are willing to follow them. Managers need to search for solutions so that compliance with the rules does not change the traditional way of living or bring socioeconomic damage to local residents.

\section{ACKNOWLEDGMENTS}

The authors are grateful to INCT-ODISSEIA Project, "Observatório das Dinâmicas Socio-Ambientais" at Universidade de Brasília (UnB) for their technical support. This work was also supported by the research project SINBIOSE "Système d'INdicateurs de BIOdiversité à l'uSage des actEurs: Biodiversité terrestre et aquatique (Amazone \& Oyapock)", under the International Cooperation Program GuyAmazonEdital \# 022/2014 (IRD/UFAM). The authors are also grateful to Coordenaçáo de Aperfeiçoamento de Pessoal de Nível Superior (Capes), Conselho Nacional de Desenvolvimento Científico e Tecnológico (CNPq) and Fundação de Amparo à Pesquisa do Distrito Federal (FAP-DF) for their financial support. Additional thanks to CEF, a research unit funded by Fundação para a Ciência e a Tecnologia I.P. (FCT), Portugal (grant UIDB/00239/2020).

\section{REFERENCES}

Agustsson, K.; Garibjana, A.; Rojas, E.; Vatn, A. 2014. An assessment of the forest allowance programme in the Juma Sustainable Development Reserve in Brazil. International Forestry Review, 16: 87-102.

Amazonas. 2007a. Governo do Estado do Amazonas. Política Estadual sobre Mudanças Climáticas Conservação Ambiental e Desenvolvimento Sustentável do Amazonas. (https://online. sefaz.am.gov.br/silt/Normas/Legisla\%E7\%E3o\%20Estadual/ Lei\%20Estadual/Ano\%202007/Arquivo/LE\%203135\%2007. htm). Accessed on 12 Oct 2021.

Amazonas. 2007b. Assembleia Legislativa do Estado do Amazonas. Lei Complementar no 53/2007, que institui o Sistema Estadual de Unidades de Conservaçáo - SEUC. (http://www.idam.am.gov. br/wp-content/uploads/2021/01/Lei-Complementar-53-2007Sistema-Estadual-de-Unidades-de-Conservação.pdf). Accessed on 12 Oct 2021.

Barlow, J.; Berenguer, E.; Carmenta, R.; França, F. 2020. Clarifying Amazonia's burning crisis. Global Change Biology, 26: 319-321.

Barona, E.; Ramankutty. N.; Hyman, G.; Coomes, O.T. 2010. The role of pasture and soybean in deforestation of the Brazilian Amazon. Environmental Research Letters, 5: e024002.

Brasil. 2002. Lei n. 9.985, de 18 de Junho de 2000: Sistema Nacional de Unidades de Conservação da Natureza (SNUC). 2da ed. MMA, Brasília, 52p.

Börner, J.; Wunder, S.; Reimer, F.; Bakkegaard, R.K.; Viana, V.; Tezza, J.; Pinto, T.; Lima, L.; Marostica, S. 2013. Promoting Forest Stewardship in the Bolsa Floresta Programme: Local Livelihood Strategies and Preliminary Impacts. Center for International Forestry Research, Bonn, 60p.

Câmara, G.; Valeriano, D.M.; Soares, J.V. 2006. Metodologia Para o Cálculo da Taxa Anual de Desmatamento na Amazônia Legal. INPE, São José Campos, 24p. (http://www.obt.inpe.br/OBT/ assuntos/programas/amazonia/prodes/pdfs/metodologia.pdf/@@ download/file/metodologia.pdf). Accessed on 13 Oct 2021.

CONAB. 2020. Companhia Nacional de Abastecimento. Política de Grarantia de Preços. (https://consultaweb.conab.gov.br/ consultas/consultaPgpm.do?method=acaoCarregarConsulta). Accessed on 13 Oct 2021.

Cisneros, E.; Borner, J.; Pagiola, S.; Wunder, S. 2019. Impacts of Conservation Incentives in Protected Areas: The case of Bolsa Floresta, Brazil. PES Learning Paper 2019-1, World Bank, Washington-DC. 30p.

Couto-Pereira, S.N. 2010. Payment for environmental services in the Amazon forest: how can conservation and development be reconciled? The Journal of Environment \& Development, 19: 171-190.

Dudley, N. (Ed.) (2008). Guidelines for Applying Protected Area Management Categories. Gland, Switzerland: IUCN.

Dutrieux, L.P.; Jakovac, C.C.; Latifah, S.H.; Kooistra, L. 2016. Reconstructing land use history from Landsat time-series: Case study of a swidden agriculture system in Brazil. International Journal of Applied Earth Observation and Geoinformation, 47: 112-124.

Evans. J.; Jones, P. 2011. The walking interview: Methodology, mobility and place. Applied Geography, 31: 849-858. 
FAS. 2018. Relatório de Atividades 2017 do Programa Bolsa Floresta. Unpublished annual activity report on BFP for 2017. Fundação Amazônia Sustentável, Manaus, 195p.

FAS. 2019. Fundação Amazônia Sustentável. Programa Bolsa Floresta, Panorama geral. (https://fas-amazonia.org/componente/ programa-bolsa-floresta/). Accessed on 12 Oct 2021.

Gebara, M.F.; Agrawal, A. 2017. Beyond rewards and punishments in the Brazilian Amazon: Practical implications of the REDD+ discourse. Forests, 8: e66.

Gomes, F.A.; Lacerda, E.G. 2015. The arrangement of livestock in sustainable development reserve Uatuma, AM, Brazil. Revista Geográfica Acadêmica, 9: 107-125.

IDESAM. 2009. Instituto de Desenvolvimento Sustentável do Amazonas. Plano de gestáo da Reserva de Desenvolvimento Sustentável do Uatumã. (https://idesam.org/publicacoes/planogestao-rds-uatuma/). Accessed on 10 Oct 2021.

INPE. 2019. Instituto Nacional de Pesquisas Espaciais. Metodologia Utilizada nos Projetos PRODES e DETER. (http://www.obt.inpe. br/OBT/assuntos/programas/amazonia/prodes/pdfs/Metodologia_ Prodes_Deter_revisada.pdf). Accessed on 17 Oct 2021

INPE. 2020. Instituto Nacional de Pesquisas Espaciais. Portal TerraBrasilis, PRODES. (http://terrabrasilis.dpi.inpe.br/app/ dashboard/deforestation/biomes/amazon/). Accessed on 15 Oct 2021.

Jakovac, C.C.; Dutrieux, L.P.; Siti, L.; Peña-Claros, M.; Bongers, F. 2017. Spatial and temporal dynamics of shifting cultivation in the middle-Amazonas river: Expansion and intensification. PloS ONE, 12: $\mathrm{e} 0181092$.

Jakovac, C.C.; Peña-Claros, M.; Kuyper, T.W.; Bongers, F. 2015. Loss of secondary-forest resilience by land-use intensification in the Amazon. Journal of Ecology, 103: 67-77

Jakovac, C.C.; Peña-Claros, M.; Mesquita, R.C.; Bongers, F.; Kuyper. W. 2016. Swiddens under transition: consequences of agricultural intensification in the Amazon. Agriculture, Ecosystems \& Environment, 218: 116-125.

Jiménez-Muñoz, J.C.; Mattar, C.; Barichivich, J.; Santamaría-Artigas, A.; Takahashi, K.; Malhi, Y.; Sobrino, J.A.; Schrier, G. 2016. Record-breaking warming and extreme drought in the Amazon rainforest during the course of El Niño 2015-2016. Scientific Reports, 6: e33130.

Kalamandeen, M.; Gloor, E.; Mitchard, E.; Quincey, D.; Ziv, G.; Spracklen, D.; Spracklen, B.; Adami, M.; Aragão, L.E.; Galbraith, D. 2018. Pervasive rise of small-scale deforestation in Amazonia. Scientific Reports, 8: 1600. doi.org/10.1038/ s41598-018-19358-2

Laques, A-E.; Cabral, A.I.R.; Silva, S.C.P.; Pereira, H.S.; Saito, C.H. 2018. Água e floresta na Reserva de Desenvolvimento Sustentável do Uatumã. Sustentabilidade em Debate, 9: 164-186.

Lintemani, M.G.; Loss, A.; Mendes, C.S.; Fantini, A.C. 2020. Long fallows allow soil regeneration in slash-and-burn agriculture. Journal of the Science of Food and Agriculture, 100: 1142-1154.
Lundberg, L.; Persson, U.M.; Alpizar, F.; Lindgren, K. 2018. Context matters: exploring the cost-effectiveness of fixed payments and procurement auctions for PES. Ecological Economics, 146: 347-358.

MapBiomas. 2018. Coleçáo da série anual de mapas de cobertura e uso de solo do Brasil. (https://mapbiomas.org/colecoes-mapbiomas1?cama_set_language=pt-BR). Accessed on 10 Oct 2021.

Maurano, L.E.P.; Escada, M.I.S.; Renno, C.D. 2019. Padrōes espaciais de desmatamento e a estimativa da exatidáo dos mapas do PRODES para Amazônia Legal Brasileira. Ciência Florestal, 29: $1763-1775$.

Moutinho, P.; Guerra R.; Azevedo-Ramos, C. 2016. Achieving zero deforestation in the Brazilian Amazon: What is missing? Elementa: Science of the Anthropocene, 4: e000125.

Paiva, P.F.P.R.; Ruivo, M.D.L.P.; Silva-Júnior, O.M.; Maciel, M.D.N.M.; Braga, T.G.M.; Andrade, M.M.N.; et al. 2020. Deforestation in protect areas in the Amazon: a threat to biodiversity. Biodiversity and Conservation, 29: 19-38.

Perez, D.; Mora, R.; Lopez-Carrascal, C. 2019. Conservation of the cassava diversity in the traditional cultivation systems of the Amazon. Acta Biológica Colombiana, 24: 202-212.

SEMA. 2017. Secretaria Estadual do Meio Ambiente do Amazonas. Revisão do plano de gestão da Reserva de Desenvolvimento Sustentável do Uatumá. (https://pdfhost.io/v/ ijbi474P_Plano_ de_Gesto_RDS_Uatuma_revisao_2018pdf.pdf). Accessed on 12 Oct 2021.

Strand, J.; Soares-Filho B.; Costa. M.H.; Oliveira U.; Ribeiro, S.C.; Pires, G.F.; et al. 2018. Spatially explicit valuation of the Brazilian Amazon Forest's Ecosystem Services. Nature Sustainability, 1: 657-664.

Van-Vliet, N.; Adams, C.; Vieira, I.C.G.; Mertz, O. 2013. "Slash and burn" and "shifting" cultivation systems in forest agriculture frontiers from the Brazilian Amazon. Society \& Natural Resources, 26: 1454-1467.

Van-Vliet, N.; Mertz, O.; Heinimann, A.; Langanke, T.; Pascual, U.; Schmook, B.; Adams, C.; Schmidt-Vogt, D.; Messerli, P.; Leisz, S. 2012. Trends, drivers and impacts of changes in swidden cultivation in tropical forest-agriculture frontiers: a global assessment. Global Environmental Change, 22: 418-429.

Viana, V.; Tezza, J.; Solidade, V.; Marostica, S.; Salviati, V.; Soares, A. 2012. Impactos do Programa Bolsa Floresta: uma avaliação preliminar. Inclusão Social, 6: 201-218.

Villa, P.M.; Martins, S.V.; Oliveira-Neto, S.N.; Rodrigues, A.C.; Martorano, L.G.; Monsanto, L.D.; Cancio, N.M.; Gastauer, M. 2018. Intensification of shifting cultivation reduces forest resilience in the northern Amazon. Forest Ecology and Management, 430: 312-320.

Vogelmann, J.E.; Rock, B.N. 1988. Assessing forest damage in highelevation coniferous forests in Vermont and New Hampshire using Thematic Mapper data. Remote Sensing of Environment, 24: $227-246$

RECEIVED: $04 / 02 / 2021$

ACCEPTED: $12 / 10 / 2021$

ASSOCIATE EDITOR: Eduardo Maeda 